управління, доцент кафедри адміністративного менеджменту та альтернативних джерел енергії, Вінницький національний аграрний університет (21008, м. Вінниця, вул. Сонячна, 3, e-mail: baldynyuk@gmail.com).

ТОМАШУК Іван Олегович - аспірант Національного наукового центру «Інститут аграрної економіки» (03127, м. Київ, вул. Героїв Оборони, 10, e-mail: pd@iae.org.ua).

TOMASHUK Inna - PhD of Economics, Senior Lecturer of the Department of Economics and Entrepreneurship, Vinnytsia National Agrarian University (21008, Vinnytsia, 3, Soniachna Str., e-mail: tomashuk.inna@ukr.net).

BALDYNYUK Vasyl - Candidate of Science in Public Administration, Associate Professor of the Department of Administrative Management and Alternative Energy Sources, Vinnytsia National Agrarian University (21008, Vinnytsia, 3, Soniachna Str., e-mail: baldynyuk@gmail.com).

TOMASHUK Ivan - postgraduate student of the National Research Center «Institute of Agrarian Economics», 03127, Kyiv, 10, Heroiv Oborony Str., e-mail: pd@iae.org.ua).

ТОМАШУК Инна Викторовна - доктор философии по экономике, старший преподаватель кафедры экономики и предпринимательской деятельности, Винницкий национальный аграрный университет (21008, г. Винница, ул. Солнечная, 3, e-mail: tomashuk.inna@ukr.net).

БАЛДИНЮК Василий Михайлович - кандидат наук по государственному управлению, доцент кафедры административного менеджмента и альтернативных источников энергии, Винницкий национальный аграрный университет (21008, г. Винница, ул. Солнечная, 3, e-mail: baldynyuk@gmail.com).

ТОМАШУК Иван Олегович - аспирант Национального научного центра «Институт аграрной экономики» $(03127$, г. Киев, ул. Героев Обороны, 10, e-mail: pd@iae.org.ua).

УДК 339.5(477+4-6€C)

DOI: 10.37128/2411-4413-2021-4-9

АНАЛІЗ ПРОБЛЕМ І
ПЕРСПЕКТИВ
ЗОВНІШНЬОЇ
ТОРГІВЛІ УКРАЇНИ
3 КРАЇНАМИ ЄС

ХАЕЦЬКА О.П., кандидат економічних наук, доцент, завідувачка кафедри економіки та підприємницької діяльності, Вінницький національний аграрний університет (м. Вінниця)

У статті проаналізовано особливості зовнішньої торгівлі Украӥни з іншими краӥнами, зокрема з краӥнами Свропейського Союзу. Розвиток зовнішньої торгівлі $\epsilon$ важливим для аналізу економічного стану краӥни, відображає ставлення країн світу до вітчизняної продукції. Визначено траєкторію розвитку зовнішньої торгівлі, щзо формує резерви підвищення рівня міжнародних торговельних відносин $i$ підвищує конкурентоспроможність української продукиії.

Наведено динаміку змін у географічній та товарній структурі міжнародної торгівлі 
товарами й послугами протягом 2018-2020 років, визначено частку Європейського Союзу в зовнішній торгівлі, який є ключовим торговельним партнером Украйни. Досліджено основні групи товарів $і$ послуг, які експортувала й імпортувала Украӥна. Обтрунтовано основні причини зменшення зовнішньоторговельного обороту. Крім того, встановлено, щз основними краӥнами-партнерами Украӥни в міжнародній торгівлі є Китай, Польща, США, Німеччина та краӥни СС.

Важливою складовою зовнішньої торгівлі України $е$ міжнародна торгівля сільськогосподарською продукиією. У статті наведено статистичні дані щзодо товарної структури аграрного експорту з крайнами ЄС. Відносини Украӥни у сфері торгівлі продукиією сільськогосподарського виробництва набули важливого значення після того, як було підписано Угоду про асоціацію між Украӥною та $Є С$, щзо забезпечує незворотність європейської інтеграџії Украйни, $і$ є першочерговою для здійснення суспільно важливих реформ.

Досліджено, щзо для покращення зовнішньоекономічної торгівлі Украӥни з краӥнами Свропейського Союзу необхідно впроваджувати заходи, які сприятимуть модернізації ключових експортно орієнтованих галузей економіки, вдосконалювати програму співпраці $з$ іншими країнами, проводити ефективну зовнішньоекономічну політику держсви, зміцнювати позииії вітчизняного товаровиробника на зовнішніх ринках товарів та послуг.

Зазначено, щьо співробітнищтво з Свропейським Союзом є одним із головних пріоритетів зовнішньоекономічної політики України. У статті наведено шляхи покращення зовнішньої торгівлі Украӥни й напрями вдосконалення зовнішньоторговельної діяльності.

Ключові слова: зовнішня торгівля, країни $С С$, експорт, імпорт, географічна структура, товарна структура, зовнішньоторговельний оборот.

Табл.: 1. Рис.: 7. Літ.: 18.

\title{
ANALYSIS OF PROBLEMS AND PROSPECTS OF UKRAINE'S FOREIGN TRADE WITH EU COUNTRIES
}

\author{
KHAIETSKA Olha, \\ Candidate of Economic Sciences, \\ Head of the Department of Economics and Entrepreneurship, \\ Vinnytsia National Agrarian University \\ (Vinnytsia)
}

The article analyzes the peculiarities of Ukraine's foreign trade with other countries, including the EU countries. The development of foreign trade is important for the analysis of the economic situation of the country, reflects the attitude of the world's countries to domestic production. The trajectory of foreign trade development is determined. It forms reserves for increasing the level of international trade relations and increases the competitiveness of Ukrainian production.

The dynamics of changes in the geographical and commodity structure of international trade in goods and services during 2018-2020 is given, the share of the European Union in foreign trade, which is a key trading partner of Ukraine, is determined. The main groups of goods and services exported and imported by Ukraine are studied. The main reasons for the decrease in foreign trade turnover are substantiated. In addition, it was established that the main partner countries of Ukraine in international trade are China, Poland, the United States, Germany and the EU countries.

The important component of Ukraine's foreign trade is international trade in agricultural products. The article presents statistical data on the commodity structure of agricultural exports with the EU countries. Ukraine's relations in the field of trade in agricultural products became important after the signing of the Association between Ukraine and the EU, which ensures the irreversibility of Ukraine's European integration and it is priority for socially important reforms. 
It is studied that in order to improve Ukraine's foreign economic trade with the European Union, it is necessary to implement measures to modernize key export-oriented sectors of the economy, improve cooperation with other countries, pursue effective foreign economic policy, and strengthen the position of domestic manufacturers in foreign markets of goods and services.

It is noted that cooperation with the European Union is one of the main priorities of Ukraine's foreign economic policy. The article presents ways to improve Ukraine's foreign trade and directions of improvement of foreign trade activity.

Key words: foreign trade, the EU countries, export, import, geographical structure, commodity structure, foreign trade turnover.

Table.: 1. Fig.: 7. Ref.: 18.

\title{
АНАЛИЗ ПРОБЛЕМ И ПЕРСПЕКТИВ ВНЕШНЕЙ ТОРГОВЛИ УКРАИНЫ СО СТРАНАМИ ЕС
}

\author{
ХАЕЦКАЯ О.П., \\ кандидат экономических наук, доцент, \\ заведующая кафедрой экономики и \\ предпринимательской деятельности, \\ Винницкий национальный аграрный университет
}

(2. Винница)

В статье проанализированы особенности внешней торговли Украиньл с другими странами, в частности со странами Европейского Союза. Развитие внешней торговли является важным для анализа экономического состояния страны, отражает отношение стран мира к отечественной продукиии. Определена траектория развития внешней торговли, что формирует резервы повышения уровня международных торговых отношений и повышает конкурентоспособность украинской продукиии.

Приведена динамика изменений в географической $u$ товарной структуре международной торговли товарами и услугами в течение 2018-2020 годов, определена доля Европейского Союза во внешней торговле, который является ключевым торговым партнером Украины. Исследованы основные группы товаров и услуг, которые экспортировала и импортировала Украина. Обоснованы основные причины уменьшения внешнеторгового оборота. Кроме того, установлено, что основнылми партнерами Украинь в международной торговле являются: Китай, Польша, США, Германия и страны EC.

Важной составляющей внешней торговли Украины является международная торговля сельскохозяйственной продукцией. В статье приведены статистические данные по товарной структуре аграрного экспорта со странами ЕС. Отношения Украинь в сфере торговли продукиией сельскохозяйственного производства приобрели важное значение после того, как было подписано Соглашение об ассочииачии Украины и ЕС, которое обеспечивает необратимость европейской интеграиии Украины и является первоочередной задачей для осуществления общественно важных реформ.

Доказано, что для улучшения внешнеэкономической торговли Украины со странами Европейского Союза необходимо внедрять мероприятия, способствующче модернизации ключевых экспортно ориентированных отраслей экономики, совершенствовать программу сотрудничества с другими странами, проводить эффективную внешнеэкономическую политику государства, укреплять позиции отечественного товаропроизводителя на внешних рынках товаров и услуг.

Отмечено, что сотрудничество с Европейским Союзом является одним из главньх приоритетов внешнеэкономической политики Украинь. B статье приведень пути улучшения внешней торговли Украины и направления совершенствования внешнеторговой деятельности. 
Ключевые слова: внешняя торговля, страны ЕС, экспорт, импорт, географическая структура, товарная структура, внешнеторговый оборот.

Табл.: 1. Рис.: 7. Лит.: 18.

Постановка проблеми. Зовнішня торгівля $є$ фактором економічного розвитку країн i важливою складовою товарного обороту, зовнішньоекономічної діяльності. Розвиток зовнішньої торгівлі забезпечує зростання ВВП країни, сприяе прибутковості вітчизняних товаровиробників i поліпшенню якості виготовленої продукції, що підвищує конкурентоспроможність товарів і послуг на світовому ринку. Зовнішня торгівля є джерелом валютних надходжень, спрямовується на збалансування виробничих можливостей країни з урахуванням споживчих переваг, забезпечує зростання національного доходу, дозволяючи надходження дефіцитних товарів та реалізацію товарів, які є в надлишку в країні, а також представляє ключові напрямки економічного розвитку країни.

Джерелом інформації для аналізу проблем і перспектив зовнішньої торгівлі України 3 країнами $Є С$ на світовому ринку $\epsilon$ статистичні дані зовнішньоторговельного балансу, географічної та товарної структури експорту й імпорту українських товарів і послуг на зовнішніх ринках.

Завдяки вдалому географічному розташуванню, випуску значної кількості конкурентоспроможної продукції, наша країна взаємодіє з економіками інших країн світу щодо зовнішньоекономічної діяльності. Водночас відносини України з СС набувають особливого значення під час визначення траєкторії розвитку й резервів підвищення рівня міжнародних торговельних відносин і підвищення конкурентоспроможності вітчизняної економіки на світовому ринку.

Основними проблемами розвитку зовнішньої торгівлі України з країнами $€ \mathrm{C} \in$ такі: низький рівень конкурентоспроможності вітчизняної продукції порівняно з більш високотехнологічними та якісними європейськими товарами, політична та економічна нестабільність у країні, недосконалість законодавства, недостатня державна підтримка, низький рівень економічного зростання тощо.

Аналіз останніх досліджень і публікацій. Проблеми й перспективи розвитку зовнішньої торгівлі України з країнами ЄС досліджено у працях багатьох вітчизняних вчених: В. Андрійчука [17], О. Білогана, А. Брояки [10], П. Гайдуцького, І. Гончарук [12, 13]， Ю.Козака, С. Кваші, І. Круп'яка [8], В. Нелепи, Ю. Ставської [14] та ін.

Питання розвитку міжнародної торгівлі досліджували представники класичної школи економічної теорії (А. Сміт, Д. Рікардо, Т. Мальтус, Дж. С. Мілль). Значний вклад у іiі розвиток та закладання підгрунтя для вивчення проблем зовнішній торгівлі України 3 іншими країнами світу здійснили представники неокласичного напрямку (В. Леонтьєв, В. Олін, Е. Хекшер).

Зовнішня торгівля, іiі розвиток набуває нових рис й особливостей у працях сучасних вітчизняних і зарубіжних науковців.

Формулювання цілей статті. Метою статті $є$ дослідження проблем i 
перспектив зовнішньої торгівлі України з країнами $Є С$, визначення основних тенденцій розвитку міжнародної торгівлі, економічний аналіз товарної та географічної структури експорту, імпорту товарів i послуг, динаміки зовнішньоторговельного обороту, визначення перспектив i пріоритетів зовнішньої торгівлі й зміцнення національної економіки.

Виклад основного матеріалу дослідження. Зовнішня торгівля $\epsilon$ формою вираження економічних зв'язків між країнами, що відображає взаємозв'язки між виробниками різних країн, які виникають на основі міжнародного поділу праці й впливає на взаємну економічну залежність. Зовнішня торгівля надає вигоду країнам, які беруть у ній участь. Дослідження особливостей міжнародної торгівлі, основні вигоди між країнами під час здійснення експортно-імпортних операцій були закладені ще у XVIII-XIX столітті Адамом Смітом і Давідом Рікардо.

Сучасний стан зовнішньої торгівлі, перспективи іiі розвитку, напрями реалізації залежать від зовнішнього середовища, соціально-економічного стану національної економіки, політичної ситуації у країні, напрямів подальшого * розвитку. Тому, важливо визначити основні економічні відносини України у с. сфері зовнішньої торгівлі з іншими країнами світу.

3 початком військового конфлікту на Сході Україні, пандемії короновірусної хвороби відбулося скорочення експорту й імпорту, що зумовлено зниженням купівельної спроможності населення країни, суттєвим обмеженням доступу до звичних ринків збуту вітчизняних товарів і послуг. Але все ж, незважаючи на це, протягом останніх 5 років відбувається відносне пожвавлення та відновлення зовнішньої торгівлі. Згідно 3 даними Національного інституту стратегічних досліджень [6], в останні місяці 2020 року відбулось поступове відновлення зовнішньої торгівлі в умовах пом'якшення карантинних обмежень, за зниження світових цін на стратегічні види ресурсів і підвищення цін на сільськогосподарські та продовольчі товари.

За підсумками 2020 року, експорт товарів і послуг України щодо 2019 року скоротився на 5008,3 млн дол. Хоч сальдо було негативне, але порівнюючи з 2015-2017 роками, починаючи з 2018 року показники експорту й імпорту почали зростати, незначно скоротились у 2020 році, що пов'язано 3 пандемією COVID-19.

У структурі експорту частка товарів у 2020 році становила 83,4\%, послуг - 16,6\%. Україна експортувала у 2021 році товари до 228 країн світу, 84,4\% належить 15 країнам - торговельним партнерам, таким як: країни Європейського Союзу, Китай, Російська Федерація, Туреччина, США, Індія, Єгипет, Білорусь, Ізраїль, Об'єднані Арабські Емірати, Індонезія, Республіка Молдова, Саудівська Аравія, Швейцарія, Ірак.

Європейський Союз $є$ головним торговельним партнером України останніми роками. За результатами 2020 року, питома вага торгівлі товарами й послугами з ЄС склала $37,2 \%$ від загального обсягу торгівлі України [1]. Основні показники зовнішньої торгівлі України відображено у табл. 1. 
EФM

http://efm.vsau.org/

Таблиия 1

Показники зовнішньої торгівлі України, млрд дол.

\begin{tabular}{|c|c|c|c|c|c|c|c|c|c|}
\hline & \multicolumn{3}{|c|}{ Експорт } & \multicolumn{3}{|c|}{ Імпорт } & \multicolumn{3}{|c|}{ Сальдо } \\
\hline & 2018 & 2019 & 2020 & 2018 & 2019 & 2020 & 2018 & 2019 & 2020 \\
\hline $\begin{array}{l}\text { Усього } \\
\text { товари й послуги }\end{array}$ & 57280,9 & 64050,3 & 59367,9 & 63493,7 & 67739,4 & 60045,7 & $-6212,8$ & $-3689,1$ & $-677,8$ \\
\hline Країни ЄС & 23100,1 & 24164,7 & 22085,2 & 26570,1 & 28738,4 & 26786,7 & $-3470,0$ & $-4573,7$ & $-4701,5$ \\
\hline $\begin{array}{l}\text { Частка краӥн ЄС } \\
\text { торгівлі товарами й } \\
\text { послугами, \% }\end{array}$ & 40,3 & 37,7 & 37,2 & 41,8 & 42,4 & 44,6 & $x$ & $x$ & $X$ \\
\hline Товари & 47335,0 & 50054,6 & 49191,8 & 57187,6 & 60800,2 & 54336,1 & $-9852,6$ & $-10745,6$ & $-5144,3$ \\
\hline Країн & 20157,0 & 20750,7 & 18604,9 & 23216,5 & 25012,2 & 23859,7 & $-3059,5$ & $-4261,5$ & $-5254,8$ \\
\hline $\begin{array}{l}\text { Частка країн ЄС } \\
\text { торгівлі товарами, } \\
\%\end{array}$ & 42,6 & 41,5 & 37,8 & 40,6 & 41,1 & 43,9 & $x$ & $x$ & $X$ \\
\hline Послуги & 11637,9 & 15628,9 & 11387,6 & 6308,8 & 6942,2 & 712,5 & 5329,1 & 8686,7 & 5675,1 \\
\hline Краї & 3979,9 & 4469,0 & 4461,1 & 3355,8 & 3728,9 & 2927,0 & 624,1 & 740,1 & 1534,1 \\
\hline $\begin{array}{l}\text { Частка країн СС у } \\
\text { торгівлі послугами, } \\
\%\end{array}$ & 34,2 & 28,6 & 39,2 & 53,2 & 53,7 & 51,2 & $x$ & $x$ & $X$ \\
\hline
\end{tabular}

Джерело: узагальнено автором на основі даних [2]

Зовнішньоторгівельний оборот України з країнами ЄС у 2019 році, порівнюючи з 2018 роком, збільшився на 5,8\%, а у 2020 році, порівнюючи 3 2019 роком, - зменшився на 9\%.

Експорт товарів і послуг до попереднього року у 2019 році становив $111,8 \%$ (збільшився на 6769,4 млн дол.), а у 2020 році до попереднього становив 92,7\% (зменшився на 4682,4 млн дол.). У країни СС експорт у 2020 році зменшився на $8,6 \%$ (на 2079,5 млн дол.), тоді як у 2019 році спостерігалось збільшення на 4,6\%, а у 2018 на 14,6\% до попереднього року.

Показники імпорту у 2020 році також погіршилися на 12,4\% (скоротилися на 7693,7 млн дол.), у 2019 році, порівнюючи з 2018 роком, - збільшилися на $6,7 \%$, а у 2018 році щодо попереднього року збільшення становило 15,3\%. Імпорт із країн СС у 2020 році, якщо порівняти з 2019 роком, скоротився на 6,8\% (на 1951,7 млн дол.), у 2019 році - збільшився на 8,2\%, у 2018 - зріс на 13,9\%, порівнюючи з попередніми роками.

Сальдо торгівлі товарами й послугами з країнами ЄС (28) є негативним у сумі 4,4 млрд дол., але покращилось, якщо порівняти 3 2019 роком, на 216,5 млн дол. [2].

Щодо зовнішньоторговельного обороту товарів і послуг України у 2020 році, то порівнюючи з 2019 роком, він зменшився на 10,2\% (на 13,5 млрд дол.) і становив 118,3 млрд дол.

Сальдо торговельного балансу товарів і послуг у 2020 році було від'ємним (255,5 млн дол.), але покращилось, якщо порівняти з 2019 роком на 3,4 млрд дол. Експорт товарів і послуг за підсумками 2020 року зменшився на 7,8\% (на 5,0 млрд дол.), порівнюючи з показниками 2019 року, і склав 59,4 млрд дол. Імпорт товарів і послуг у 2020 році зменшився на $12,5 \%$ (на 8,4 млрд дол.), якщо порівнювати з показниками 2019 року, і становив 59,3 млрд дол. [2].

Зміни в динаміці міжнародної торгівлі, зменшення імпорту й експорту 
пов'язані зі зниженням промислового виробництва в більшості країн, загостренням військових конфліктів, перевищенням пропозиції над попитом, зміною світових цін на важливі сировинні товари й ресурси, застосуванням політики протекціонізму, зміною пріоритетів деяких країн щодо торговельних партнерів, валютними коливанями тощо.

Варто відзначити, що скорочення експортно-імпортних операцій змінилось як за товарами, так і загалом за послугами з країнами СС.

В останні роки відбулися зміни й у використанні Україною тарифних квот $\mathrm{CC}$, зокрема, і для товарів, які мають високий ступінь обробки. Так, у 2020 році українські експортери використали 31 з 40 тарифних квот у рамках Угоди про зону вільної торгівлі з країнами СС, у 2019 й 2018 роках 32 тарифні квоти, тоді як у 2017 році - 29 тарифні квоти, у 2016 році 26 тарифні квоти [3].

У 2020 році повністю використано 11 тарифних квот на: кукурудзу, ячмінну крупу та борошно, цукор, мед, яйця, м'ясо птиці, альбуміни, виноградний та яблучний соки, оброблений крохмаль, оброблені томати, продукти переробки солоду й крохмалю та оброблену продукцію із зернових.

Структуру міжнародної торгівлі доцільно розглядати в географічному й товарному аспектах. Основними торговельними партнерами України у 2020 році були країни ЄС, Російська Федерація, Китай, Туреччина, Індія та інші країни. Експорт товарів у 2020 року до країн ЄС становив 18612,1 млн дол. $(89,7 \%$ до 2019 року), а саме: до Китаю - 7112,7 млн дол. (198,0\%), до Туреччини 2436,3 млн дол. (93,0\%), до Індії 1972,1 млн дол. (97,4\%), до США 983,9 млн дол. (100,5\%), до Саудівської Аравії - 719,0 млн дол. (100,1\%).

Основні країни-партнери в експорті й імпорті товарів у 2019-2020 роках відображено на рис. 1 та рис. 2.

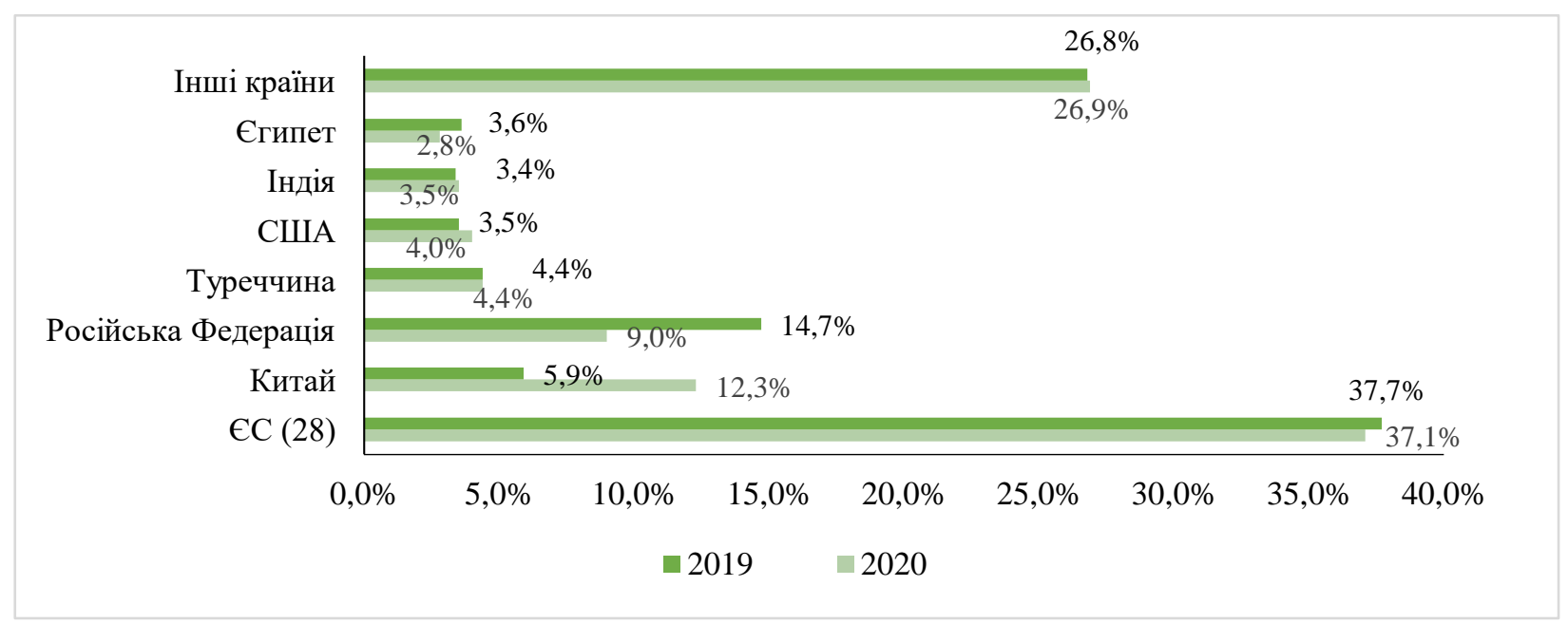

Рис. 1. Основні країни-партнери України в експорті товарів у 2019-2020 роках

Джерело: побудовано автором на основі [4, 5]

Зокрема, найбільше Україна співпрацює з Китаєм, Польщею, США й Німеччиною. Незважаючи на військовий конфлікт із Російською Федерацією, 
Україна має з нею торговельні відносини, оскільки товари, що імпортуються, це товари стратегічного призначення (нафта та нафтопродукти, вугілля, мінеральні добрива, ядерне паливо), але, якщо порівнювати 2020 р. та 2019 р., то спостерігається значне скорочення торгівлі з Росією.

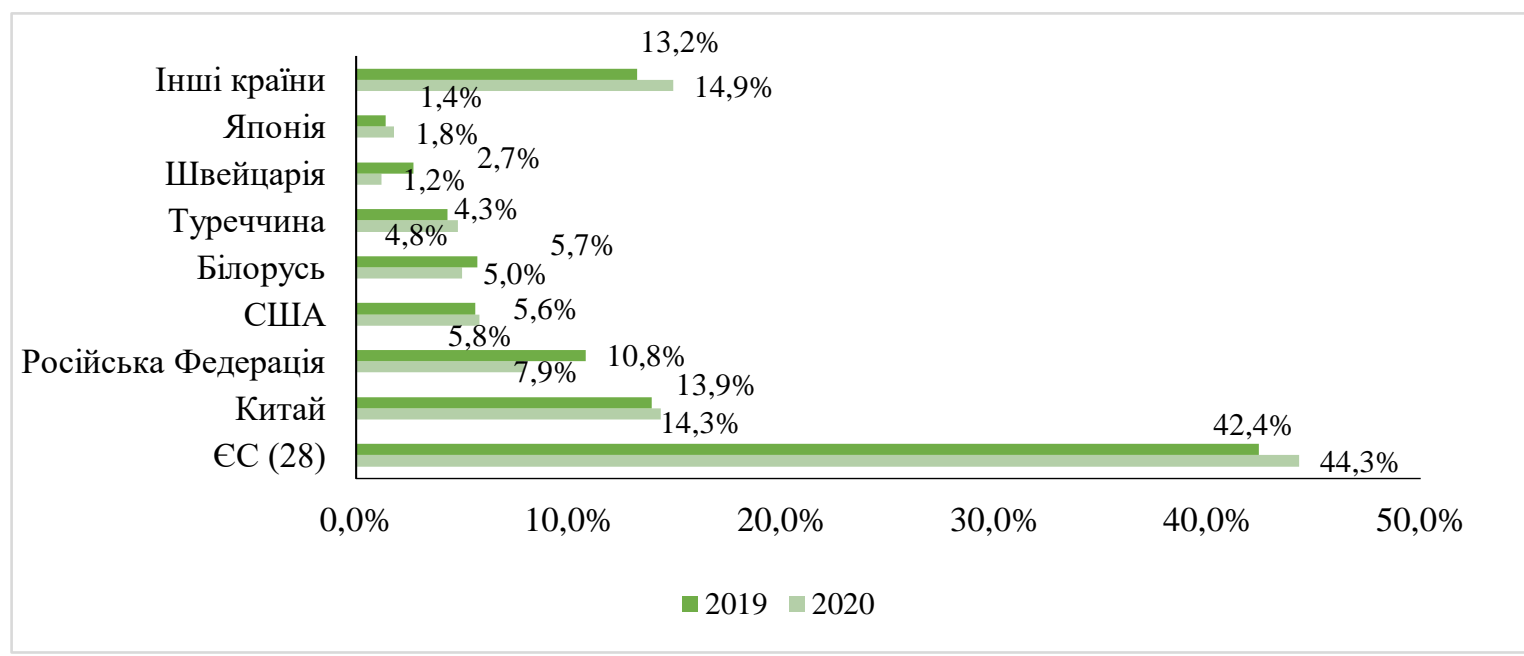

\section{Рис. 2. Основні країни-партнери України в імпорті товарів} у 2019-2020 роках

Джерело: побудовано автором на основі [4, 5]

Крім того, в України є домовленості з Індонезією, В’єтнамом, Сгиптом, Тунісом й іншими країнами Середземноморського регіону й Близького Сходу щодо угод про вільну торгівлю.

За результатами 2020 року, країни $С$ С залишаються ключовим торговельним партнером України.

Головне завдання нашої держави, яке зазначено в «Національній економічній стратегії-2030», - зробити українську продукцію доступною на зовнішніх ринках. Для цього необхідно надалі розвивати аграрний сектор, надавати державну підтримку підприємствам, здійснювати ефективну кадрову політику, впроваджувати інновації, залучати інвестиції, застосовувати ефективну податкову, кредитну політику тощо.

Серед регіонів України найбільші негативні зміни у динаміці експорту товарів 2020 року спостерігалися у Донецькій $(-1,4 \%)$, Дніпропетровській $(-0,6 \%)$, Запорізькій $(-0,3 \%)$, Закарпатській $(-0,3 \%)$, Івано-Франківській $(-0,3 \%)$, Вінницькій областях $(-0,2 \%)$. Сумарний внесок вищенаведених регіонів становив $3,1 \%$. Черкаська, Волинська, Чернівецька області, місто Київ, Житомирська, Одеська й Луганська області також продемонстрували негативну динаміку в експорті товарів. Водночас, за підсумками 2020 року, Полтавська й Кіровоградська області додали найбільшого позитивного внеску до приросту експорту товарів - кожна по 0,4\%.

За даними Державної служби статистики України [4], обсяг торгівлі товарами й послугами з СС знизився на 9\% у 2020 році, порівнюючи 3 2019 роком, та становив 48,1 млрд дол. США. Географічну структуру експорту й імпорту товарами й послугами України 3 країнами СС у 2020 році представлено на рис. 3 та рис. 4. 


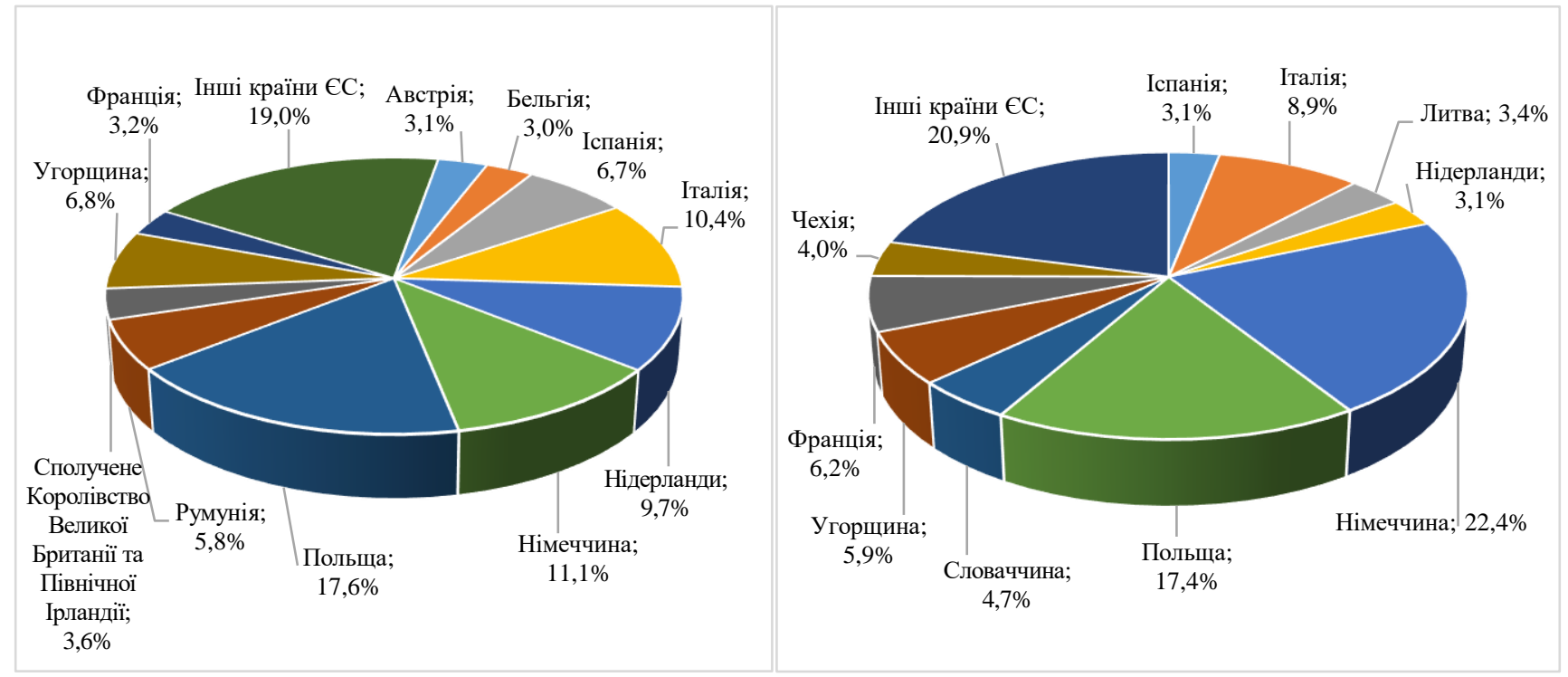

Puc. 3. Географічна структура експорту товарами та послугами України 3 країнами ЄС у 2020 році, \%
Рис. 4. Географічна структура імпорту товарами та послугами України 3 країнами ЄС у 2020 році, \%

Джерело: побудовано автором на основі [4, 5]

Вітчизняні товари та послуги Україна експортувала у 2020 році до Польщі (17,6\%), Німеччини (11,1\%), Італії (10,4\%), Нідерландів $(9,7 \%)$, Іспанії (6,7\%), Франції (6,2\%) та інших країн.

Найбільше Україна імпортує з Німеччини $(22,4 \%)$, Польщі $(17,4 \%)$, Італії (8,9\%), Франції (6,2\%), Угорщини (5,9\%) та інших країн СС.

Як правило, країни експортують ті товари, виробництво яких $\epsilon$ вигіднішим саме у цій країні, а імпортують ті товари, які не вигідно та не раціонально виготовляти самостійно, через їх трудомісткість чи відсутність певних ресурсів. У розвинутих країнах, зазвичай, експорт перевищує імпорт, а це свідчить про те, що країна має достатню кількість ресурсів і може виробляти товари не лише для внутрішнього, але й для зовнішнього ринку, чим збільшує свої макроекономічні показники. В Україні, на жаль, імпорт перевищує експорт, а це, зі свого боку, відображається в погіршенні фінансового становища у країні. Використовуючи переважно кредитні кошти, внутрішній ринок насичується імпортними товарами, що негативно впливає на конкурентне середовище у країні та іiі макроекономічну стабільність.

Основними товарами, що експортувала Україна у 2020 році були такі: продукція АПК і харчової промисловості $(45,1 \%)$, продукція металургійного комплексу (18,3\%), продукція машинобудування (11,0\%), мінеральні продукти $(10,8 \%)$, продукція хімічної промисловості (5,5\%). Проте, на деякі товари експорт скоротився, зокрема: соєві боби, подрібнені або неподрібнені, кукурудза, насіння свиріпи або ріпаку подрібнене або неподрібнене, феросплави, прутки й бруски з вуглецевої сталі без подальшого оброблення, нафтопродукти, труби, трубки й профілі порожнисті, проводи ізольовані. Товарна структура експорту й імпорту України у 2020 році представлена на рис. 5 та рис. 6. 


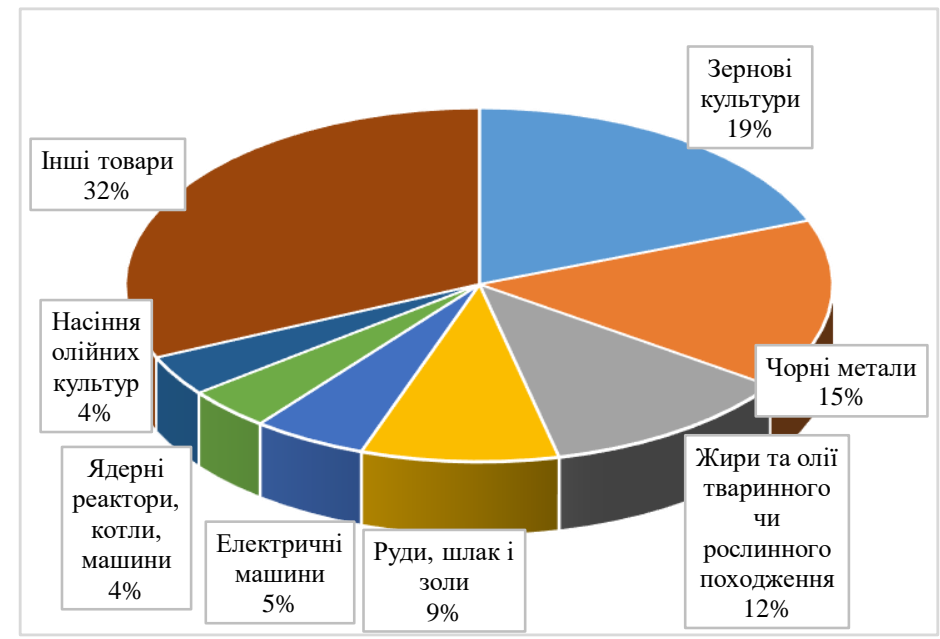

Рис. 5. Товарна структура експорту України у 2020 році, \%

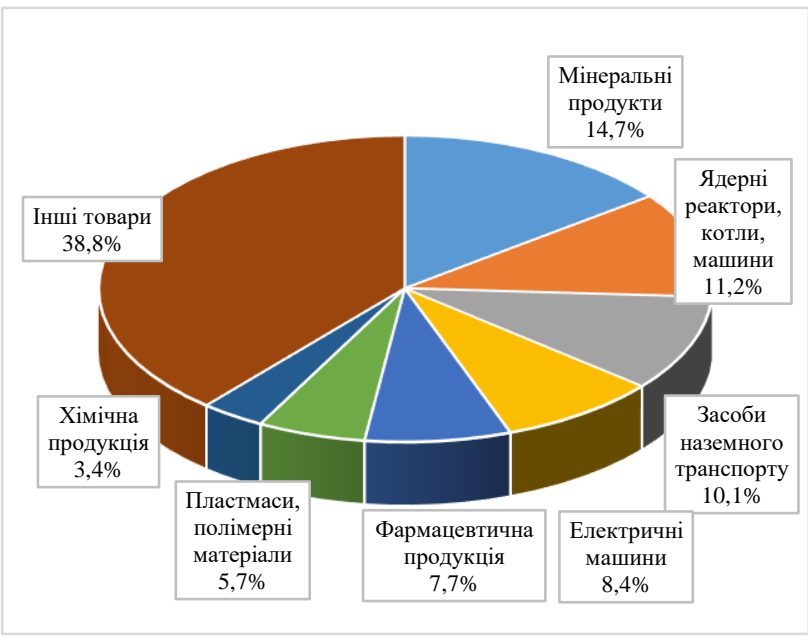

Рuc. 6. Товарна структура імпорту України у 2020 році, \%

Джерело: побудовано автором на основі [4, 6]

Найбільша частка у загальному обсязі імпорту припадає на: продукцію машинобудування $(34,3 \%)$, продукцію хімічної промисловості $(2,0 \%)$, мінеральні продукти $(15,0 \%)$, продукцію АПК та харчової промисловості $(12,0 \%)$, продукцію металургійного комплексу $(5,8 \%)$, продукцію легкої промисловості $(5,5 \%)[2,6]$.

До основних товарних категорій українського експорту в СС належать такі: зернові культури $-19 \%$, чорні метали $-15 \%$, жири та олії $-12 \%$, руди, шлаки $-9 \%$, електричні машини $-5 \%$, насіння та плоди олійних рослин $-4 \%$ тощо.

У імпорті з СС до України домінують такі товарні категорії: ядерні реактори, котли, машини - 13,3\%; засоби наземного транспорту, крім залізничного, - $11,6 \%$; електричні машини й устаткування - 8,4\%; фармацевтична продукція - 7,7\%; енергетичні матеріали - 6,9\%; пластмаси, полімерні матеріали - 5,7\%; різноманітна хімічна продукція - 3,4\%; папір і картон $-2,5 \%$ [7, с. 47].

Обсяг торгівлі товарами між Україною і СС протягом 2020 року становив 42,1 млрд доларів США, що на 8,1\% менше ніж у 2019 році. Водночас, експорт товарів до країн СС знизився на 10,3\% і становив 18,6 млрд дол. США, а імпорт товарів знизився на $6,2 \%$ та становив 23,5 млрд дол. США.

Обсяг торгівлі послугами між Україною та СС у 2020 році становив 7,1 млрд дол. США, що на 14\% менше ніж у 2019 році. Експорт послуг до країн СС знизився на 4,8\% та становив 4,3 млрд дол. США. Імпорт послуг з СС знизився на $25 \%$ та становив 2,8 млрд дол. США.

До основних категорій експорту послуг до ЄС належать: послуги у сфері телекомунікацій - 31,9\%, транспортні послуги - 25,4\%, послуги 3 переробки матеріальних ресурсів - 23,1\%, ділові послуги - 13,2\%, послуги з ремонту й технічного обслуговування - $1,8 \%$.

У імпорті послуг з СС до України домінують: ділові послуги - 22,4\%, транспортні послуги - 19,6\%, роялті й інші права інтелектуальної власності - 
$15,1 \%$, послуги у сфері телекомунікацій - 13,9\%, послуги, пов'язані 3 фінансовою діяльністю - 10,4\% [2].

Вагомий вплив на розвиток економіки країни здійснює імпорт товарів, особливо тих, які $\epsilon$ дефіцитними, тому наявність сировинних матеріалів, налагодження сталих виробничих зв'язків 3 іноземними партнерами, впровадження нових технологій, ввезення наукоємних товарів сприятиме зростанню конкуренції та стимулюватиме підвищення рівня виробництва на території нашої країни [8, с. 161].

Сальдо торгівлі з країнами $\mathrm{EC}$, за підсумками 2020 року, залишилось негативним для України, однак дещо скоротилось (-4,4 млрд дол. США), у 2019 р. сальдо становило -4,6 млрд дол. США [2].

У 2020 році значно скоротилась експортно-імпортні операції з країнами ЄС. Найбільше експортується продовольчих товарів (частка в товарній структурі експорту становить $45,1 \%$ ), водночас скоротився експорт металів і виробів із них до $18,4 \%$. Ці дві групи займають майже дві третини від загального експорту товарів з України [1].

Скорочення надходжень від експорту за підсумками 2020 р. відбулось за допомогою зменшення надходжень від експорту металів і виробів із них (скоротилися на 1,2 млрд дол. США). Скоротився експорт паливно-енергетичних товарів (на 307 млн дол. США або на 35,6\%) і машин, устаткування та транспорту (на 98 млн дол. США або на 1,8\%). Також відбулось зменшення поставок транспортних засобів і запасних частин до них на 1,4 млрд дол. США (або на 81,6\%) і промислових товарів на 652,9 млн дол. США (або на 5,7\%). Тоді як експорт продовольчих товарів та напоїв зріс на 76,1 млн дол. США або на 1,8\%. Також відбулось зростання експорту мінеральних продуктів на 772 млн дол. США або на 19,3\%.

Важливою складовою зовнішньої торгівлі України $є$ міжнародна торгівля сільськогосподарською та продовольчою продукцією i продукцією машинобудування. Україна постійно розширює зовнішньоторгівельні відносини 3 іншими країнами, зокрема i 3 Свропейським Союзом.

Відносини України з країнами Свропейського Союзу у сфері торгівлі сільськогосподарською продукцією набули важливого значення після того, як було підписано Угоду про асоціацію. Між Україною та ЄС з'явилась можливість переорієнтувати торгівлю із ринками СНД і Росії та, водночас, перейняти європейський досвід [9].

Наша країна посідає одне з провідних місць у світі за обсягами експорту зерна, має значні можливості в аграрному секторі, входить у десятку найбільших країн-експортерів продовольчих товарів сировинного характеру. Проте, експорт вітчизняних товарів i послуг залишається дещо вузькоспрямованим, товари, які експортуються, мають низький рівень переробки й низьку додану вартість, що вказує на неефективне використання наявних природних ресурсів.

Товарна структура аграрного експорту з країнами СС у 2019-2020 роках зображено на рис. 7. 


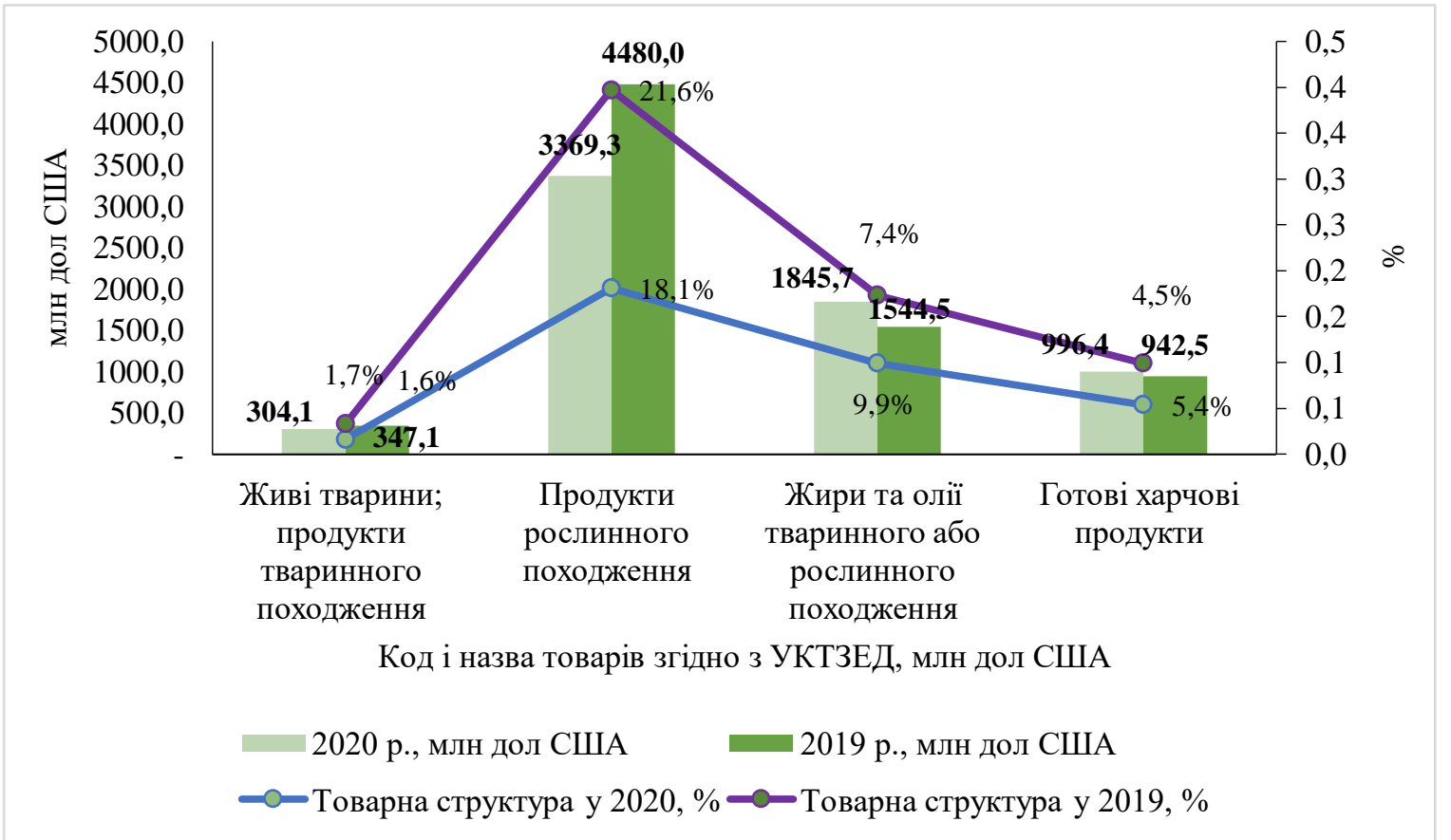

\section{Рис. 7. Товарна структура аграрного експорту України з країнами СС у 2019-2020 роках \\ Джерело: побудовано автором на основі [4]}

Як можна прослідкувати 3 діаграми, відбулося збільшення у структурі експорту продуктів рослинного походження з $18,1 \%$ у 2019 році до $21,6 \%$ у 2020 році. Щодо інших позицій (живі тварини, продукти тваринного походження, готові харчові продукти, жири й олії тваринного й рослинного походження), то у 2020 році їхня структура незначно скоротилась.

Експорт сировинної продукції аграрного сектора займає більше $30 \%$ від загального обсягу експорту України, а частка експорту готових харчових продуктів - близько 5-7\%, що свідчить про сировинну орієнтацію сільськогосподарського виробництва України та низьку додану вартість, що водночас зменшує надходження до держбюджету й зменшує приріст ВВП $[10$, c. 151$]$.

Для поліпшення зовнішньої торгівлі, зокрема аграрного експорту, необхідно вести внутрішню політику стимулювання виробництва не лише сировини, але й якісних i безпечних товарів i послуг, що сприятиме ефективному економічному розвитку України [11, с. 83].

Важливим аспектом стабільності зовнішньоекономічної торгівлі є надійне функціонування сільськогосподарських підприємств і забезпечення власними паливно-енергетичними ресурсами. У структурі енергоспоживання АПК України значну частку займають нафтопродукти, електроенергія, теплоенергія та природний газ. Україна $\epsilon$ імпортозалежною, тому для досягнення енергетичної незалежності потрібно використовувати власний потенціал агропромислового комплексу для збільшення виробництва відновлюваної енергії. Аграрний сектор має достатній потенціал для підвищення енергоефективності й переходу на відновлювані джерела енергії задля забезпечення енергетичної незалежності країни й скорочення імпорту 
енергетичних ресурсів [12, с. $94 ; 13$, с. 31$]$.

Підвищення конкурентоспроможності вітчизняних товарів поліпшується через постійне здійснення інноваційної політики, впровадження енерго- й ресурсозберігаючих технологій, застосування механізації та автоматизації виробництва, впровадження науково-технічного й технологічного оновлення виробництва тощо.

Саме торгівля з Європейським Союзом, одним із найбільших торгових ринків світу, дає можливість експортувати товари агропромислового комплексу i, у такий спосіб, покращувати економічні показники. Основні інструменти та заходи, які потрібно застосовувати для покращення зовнішньої політики, такі: митно-тарифні інструменти (мито, митні збори для регулювання зовнішньоторговельних потоків); ліцензування зовнішньоторговельних операцій i ïx контингентування (встановлення відповідних квот на експорт/імпорт окремих товарів чи груп товарів, розвиток експортного потенціалу країни, стимулювання експорту, запровадження політики протекціонізму для імпортних товарів і політики фритридерства для експортних, привести обсяг безмитної торгівлі до нинішнього експортного рівня агросектору, застосування державної монополії на здійснення окремих видів зовнішньоторговельних операцій тощо.

Для продовження нарощування темпів економічної співпраці з країнами ЄС й іншими державами світу, Україні необхідно завершити розпочаті реформи, поліпшити діловий та інвестиційний клімат, проводити боротьбу 3 корупцією, посилювати дію самоврядування [15, с. 59].

Покращення темпів економічного розвитку України й зміна структури експорту можлива через скорочення частки експорту сировини, збільшення випуску диверсифікованих та наукомістких товарів, нарощення темпів виробництва товарів із високою доданою вартістю та ін.

Співробітництво 3 країнами Європейського Союзу $\epsilon$ одним iз пріоритетних напрямів зовнішньоекономічної політики України, тому варто активно впроваджувати заходи, які будуть спрямовані на поглиблення співпраці між Україною та Європейським Союзом, зокрема:

- удосконалення законодавчої бази щодо регулювання експортноімпортних операцій;

- проведення ефективної зовнішньоекономічної політики держави;

- захист прав й інтересів вітчизняних і зарубіжних суб’єктів господарської діяльності;

- посилення конкурентоспроможності українських товарів та послуг, збільшення їх експорту;

- збільшення експорту товарів із високим рівнем доданої вартості;

- сприяння залученню іноземних інвестицій;

- забезпечення функціонування механізмів кредитування та страхування експорту за участю держави;

- контроль надходжень в Україну валютних цінностей;

- зміцнення позицій вітчизняного товаровиробника на зовнішніх ринках товарів і послуг;

- досягнення енергетичної незалежності через збільшення виробництва 
відновлюваної енергії;

- створення ТНК, інтеграція у світове виробництво;

- вивчення досвіду ЄС із актуальних питань для розвитку зовнішньої торгівлі;

- застосування практики антидемпінгових і спеціальних заходів із питань торговельного захисту вітчизняного виробника тощо.

На нашу думку, чинна Угода про вільну торгівлю між Україною та Європейським союзом має мало спільного з вільною торгівлею, адже квоти, мита, торговельні обмеження, проблеми з перевезеннями не ліквідовані i, як наслідок, українські товари не мають реального вільного доступу на ринок ЄС. Україна має проводити переговори 3 країнами $\mathrm{CC}$, базуючись на аналізі наслідків від торгівлі з ЄС, опитуванні українських виробників та думці найбільших бізнес-об'єднань.

Україна має домогтися поліпшення Угоди про вільну торгівлю у таких сферах: перегляд економічної частини Угоди про асоціацію, врегулювання торговельно-економічних питань між Україною та СС і формування політики розвитку внутрішнього виробництва в Україні несировинної продукції, проти чого часто виступають представники ЄС.

Важливим фактором, який поліпшить взаємовідносини України та ЄС у зовнішній торгівлі, буде орієнтування на впровадження пакету заходів Green Deal, які Європа уже активно застосовує. Зовнішньоторговельна політика України у наступних роках має модернізуватися за багатьма складовими, а саме: перегляд умов зони внутрішньої торгівлі з СС протягом 5 років, зміни в переліку квотованих товарів, безмитного ввезення, дзеркальних квот; у межах підготовки «Національної економічної стратегії-2030» розроблено окремий розділ щодо стратегічного торговельного курсу України [16].

Висновки. Отже, Україна може використовувати досвід іноземних держав, але обов'язковим $є$ врахування сучасного стану економіки України. Європейський Союз $є$ найбільшим торговельним партнером України, частка торгівлі у 2020 році становила більше 40\%. Експорт товарів 3 України до країн ЄС становив $85 \%$, у структурі послуг - 15\%. На ринку аграрної продукції $34 \%$ експорту України спрямовується до Європи. Товарообіг між Україною та ЄС склав у 2020 році 42,4 млрд дол., експорт із України - 18,66 млрд дол., а імпорт з $Є С-23,74$ млрд дол.

Україна у сфері зовнішньої торгівлі повинна нарощувати темпи обсягів експорту вітчизняних товарів i послуг із високою доданою вартістю. Проведення ефективної політики імпортозаміщення поліпшить зовнішньоторговельний баланс i забезпечить національну безпеку нашій державі. Формування державних фінансових резервів сприятиме підтримці українського експорту й збалансованості української зовнішньої торгівлі.

\section{Список використаних джерел:}

1. Бюлетень стану торговельних відносин між Україною та $Є С$ у 2020 році. URL: https://www.me.gov.ua/Documents/Detail?lang=uk-UA\&id=2d4 7dab0-2594-4372-836c-2b636928f34a\&title=BiuletenPotochnogoStanuTorgovelnikh 
VidnosinMizhUkrainoiuTas (дата звернення: 17.08.2021).

2. Зовнішня торгівля України товарами та послугами у 2020 році. URL: https://www.me.gov.ua/Documents/Detail?lang=uk-UA\&id=76438c62-5e54-4931ad98-7fe59d004a2a\&title=ZovnishniaTorgivliaUkrainiTovaramiTaPoslugamiU2020Rotsi (дата звернення: 17.08.2021).

3. Безмитні тарифні квоти та їхне використання. URL: https://euua.kmu.gov.ua/zona-vilnoi-torhivli/bezmytni-taryfni-kvoty-ta-yihnie-vykorystannia (дата звернення: 17.08.2021)

4. Державна служба статистики України. URL: http://www.ukrstat.gov.ua/ (дата звернення: 05.07.2021).

5. Міністерство розвитку економіки, торгівлі та сільського господарства України. Експорт товарів та послуг України. URL: https://www.me.gov.ua/?lang=uk-UA (дата звернення: 17.08.2021).

6. Національний інститут стратегічних досліджень. Щодо зовнішньої торгівлі товарами України у 2020 p. URL: https://niss.gov.ua/sites/default/files/2021-01/zed-2020.pdf (дата звернення: 17.08.2021).

7. Зовнішня торгівля України за 2020 рік. Статистичний збірник. Державна служба статистики України. Київ, 2021. 132 с.

8. Круп'як І.Й. Вектори зовнішньої торгівлі держави в умовах сучасних економічних перетворень. Вісник Миколаївського національного університету імені В.О. Сухомлинського. Економічні науки. 2017. Вип. 20. С. 158-162.

9. Пахуча Е.В., Філімонов Ю.Л., Лещенко Л.О. Структурні зміни зовнішньої торгівлі України аграрною продукцією. Ефективна економіка. 2019. № 3. URL: http://www.economy.nayka.com.ua/pdf/3_2019/50.pdf. DOI: 10.32702/2307-2105-2019.3.48 (дата звернення: 05.07.2021).

10. Брояка А.А. Перспективи розвитку зовнішньоекономічної діяльності підприємств АПК. Економіка, фінанси, менеджмент: актуальні питання науки і практики. 2020. № 1 (51). C. 146-159. DOI: 10.37128/2411-4413-2020-1-10.

11. Хаєцька О.П. Сучасні тенденції зовнішньоекономічної діяльності України. Економіка. Фінанси. Право. 2017. № 2. С. 79-83.

12. Гончарук I.B. Сучасний стан енергозабезпечення агропромислового комплексу України. Економіка та держава. 2020. № 10. C. 93-98. DOI: 10.32702/2306-6806.2020.10.93.

13. Гончарук I.В. Енергетична незалежність АПК на засадах сталого розвитку. Інвестииії: практика та досвід. 2020. № 17-18. С. 29-36. DOI: 10.32702/2306-6814.2020.17-18.29.

14. Ставська Ю.В., Глуха А.О. Перспективи розвитку зовнішньоекономічної діяльності України в умовах євроінтеграції. Приазовський економічний вісник. 2018. Вип. 5 (10). С. 59-64.

15. Алавердян Л.М., Романенко О.В. Сучасні реалії та перспективи розвитку зовнішньої торгівлі України з іншими країнами світу. Ефективна економіка. 2019. № 4. URL: http://www.economy.nayka.com.ua/pdf/4_2019/55.pdf. DOI: 10.32702/2307-2105-2019.4.53 (дата звернення: 17.08.2021).

16. Качка T. Немає підстав вводити обмеження експорту зернових. URL: 
https://agropolit.com/interview/856-taras-kachka-nemaye-pidstav-vvoditi-obmejennyaeksportu-zernovih (дата звернення 17.08.2021).

17. Андрійчук В.Г., Іванов Є.І. Вплив угоди про асоціацію між Україною та $\mathrm{CC}$ на митно-тарифне регулювання і зовнішньоторговельний режим сторін. Зовнішня торгівля: економіка, фінанси, право. 2014. № 3. С. 4-15.

18. Непрядкіна Н.В. Особливості й перспективи розвитку зовнішньої торгівлі України і ЄС сільськогосподарською продукцією. Вісник Харківського національного університету імені В.Н. Каразіна. Серія «Міжнародні відносини. Економіка. Країнознавство. Туризм». 2018. № 7. С. 60-65.

\section{References}

1. Biuleten stanu torhovelnykh vidnosyn mizh Ukrainoiu ta YeS u 2020 rotsi [Bulletin of the state of trade relations between Ukraine and the EU in 2020]. me.gov.ua. Retrieved from: https://www.me.gov.ua/Documents/Detail?lang=ukUA\&id=2d47dab0-2594-4372-836c-

2b636928f34a\&title=BiuletenPotochnogoStanuTorgovelnikhVidnosinMizhUkrainoiu Tas [in Ukrainian].

2. Zovnishnia torhivlia Ukrainy tovaramy ta posluhamy u 2020 rotsi [Ukraine's foreign trade in goods and services in 2020]. me.gov.ua. Retrieved from: https://www.me.gov.ua/Documents/Detail?lang=uk-UA\&id=76438c62-5e54-4931ad98-7fe59d004a2a\&title=ZovnishniaTorgivliaUkrainiTovaramiTaPoslugamiU2020Rotsi [in Ukrainian].

3. Bezmytni taryfni kvoty ta yikhnie vykorystannia [Duty-free tariff quotas and their use]. eu-иa.kmu.gov.ua. Retrieved from: https://eu-ua.kmu.gov.ua/zona-vilnoitorhivli/bezmytni-taryfni-kvoty-ta-yihnie-vykorystannia [in Ukrainian].

4. Ofitsiinyi sait Derzhavnoi sluzhby statystyky Ukrainy [Official site of the State Statistics Service of Ukraine]. ukrstat.gov.ua. Retrieved from: http://www.ukrstat.gov.ua/ [in Ukrainian].

5. Ministerstvo rozvytku ekonomiky, torhivli ta silskoho hospodarstva Ukrainy. Esport tovariv ta posluh Ukrainy [Ministry of Economic Development, Trade and Agriculture of Ukraine. Export of goods and services of Ukraine]. me.gov.ua. Retrieved from: https://www.me.gov.ua/?lang=uk-UA [in Ukrainian].

6. Natsionalnyi instytut stratehichnykh doslidzhen. Shchodo zovnishnoi torhivli tovaramy Ukrainy u 2020 rotsi [National Institute for Strategic Studies. Regarding foreign trade in goods of Ukraine in 2020]. niss.gov.ua. Retrieved from: https://niss.gov.ua/sites/default/files/2021-01/zed-2020.pdf [in Ukrainian].

7. Zovnishnia torhivlia Ukrainy za 2020 rik. Statystychnyi zbirnyk [Ukraine's foreign trade, 2020. Statistical publication]. Kyiv: State Statistics Service of Ukraine [in Ukrainian].

8. Krupyak, I.Ya. (2017). Vektory zovnishnoi torhivli derzhavy v umovakh suchasnykh ekonomichnykh peretvoren [Vectors of foreign trade of the state in the conditions of modern economic transformations]. Visnyk Mykolaivskoho natsionalnoho universytetu imeni V.O. Sukhomlynskoho. Ekonomichni nauky Bulletin of the V.O. Sukhomlynskyi National University of Mykolaiv. Economic 
sciences, 20, 158-162 [in Ukrainian].

9. Pakhucha, E.V., Filimonov, Yu.L., \& Leshchenko, L.O. (2019). Strukturni zminy zovnishnoi torhivlia Ukrainy ahrarnoiu produktsiieiu [Structural changes in Ukraine's foreign trade in agricultural products]. Efektyvna ekomika - Efficient economy, 3. Retrieved from: http://www.economy.nayka.com.ua/pdf/3_2019/50.pdf. DOI: 10.32702/2307-2105-2019.3.48 [in Ukrainian].

10. Broiaka, A.A. (2020). Perspektyvy rozvytku zovnishnoekonomichnoi diialnosti pidpryiemstv APK [Prospects for the development of foreign economic activity of agricultural enterprises]. Ekonomika, finansy, menedzhment: aktualni pytannia nauky i praktyky - Economics, finance, management: topical issues of science and practical activity, 1 (51), 146-159. DOI: 10.37128/2411-4413-2020-1-10 [in Ukrainian].

11. Khaietska, O.P. (2017). Suchasni tendentsii zovnishnoekonomichnoi diialnosti Ukrainy [Current trends in foreign economic activity of Ukraine]. Ekonomika. Finansy. Pravo - Economy. Finances. Right, 2, 79-83 [in Ukrainian].

12. Honcharuk, I.V. (2020). Enerhetychna nezalezhnist APK na zasadakh staloho rozvytku [Energy independence of agro-industrial complex on the basis of sustainable development]. Investytsiyi: praktyka ta dosvid - Investments: practice and experience, 17-18, 29-36. DOI: 10.32702/2306-6806.2020.10.93 [in Ukrainian].

13. Honcharuk, I.V. (2020). Suchasnyi stan enerhozabezpechennia ahropromyslovoho kompleksu Ukrainy [The current state of energy supply of the agro-industrial complex of Ukraine]. Ekonomika ta derzhava Economy and state, 10, 93-98. DOI: 10.32702/2306-6814.2020.17-18.29 [in Ukrainian].

14. Stavska, Yu.V., \& Hlukha, A.O. (2018). Perspektyvy rozvytku zovnishnoekonomichnoi diialnosti Ukrainy v umovakh yevrointehratsii [Prospects for the development of Ukraine's foreign economic activity in the context of European integration]. Pryazovskyi ekonomichnyi visnyk - Priazovsky Economic Bulletin, 5 (10), 59-64 [in Ukrainian].

15. Alaverdian, L.M., \& Romanenko, O.V. (2019). Suchasni realii ta perspektyvy rozvytku zovnishnoi torhivli ukrainy z inshymy krainamy svitu [Modern realities and prospects of Ukraine's foreign trade with other countries]. Efektyvna ekonomika - Efficient economy, 4. DOI: 10.32702/2307-2105-2019.4.53. Retrieved from: http://www.economy.nayka.com.ua/pdf/4_2019/55 [in Ukrainian].

16. Kachka T. Nemaie pidstav vvodyty obmezhennia eksportu zernovyk [There are no grounds to impose restrictions on grain exports]. agropolit.com. Retrieved from: https://agropolit.com/interview/856-taras-kachka-nemaye-pidstav-vvoditiobmejennya-eksportu-zernovih [in Ukrainian].

17. Andriichuk, V.H., \& Ivanov, Ye.I. (2014). Vplyv uhody pro asotsiatsiiu mizh Ukrainoiu ta YeS na mytno-taryfne rehuliuvannia i zovnishnotorhovelnyi rezhym storin [The impact of the Association Agreement between Ukraine and the EU on customs and tariff regulation and foreign trade regime of the parties]. Zovnishnia torhivlia: ekonomika, finansy, pravo - Foreign trade: economics, finance, 
law, 3, 4-15 [in Ukrainian].

18. Nepriadkina, N.V. (2018). Osoblyvosti y perspektyvy rozvytku zovnishnoi torhivli Ukrainy i YeS silskohospodarskoiu produktsiieiu [Features and prospects of development of foreign trade of Ukraine and the EU in agricultural products]. Visnyk Kharkivskoho natsionalnoho universytetu imeni V.N. Karazina. Seriia «Mizhnarodni vidnosyny. Ekonomika. Krainoznavstvo. Turyzm»-Bulletin of V.N. Karazin Kharkiv National University. Series «International Relations. Economy. Local lore. Tourism», 7, 60-65 [in Ukrainian].

\section{Інформація про автора}

ХАЄЦЬКА Ольга Петрівна - кандидат економічних наук, доцент, завідувачка кафедри економіки та підприємницької діяльності, Вінницький національний аграрний університет (21008, м. Вінниця, вул. Сонячна, 3, e-mail: haetska@vsau.vin.ua).

KHAIETSKA Olha - Candidate of Economic Sciences, Associate Professor, Head of the Department of Economics and Entrepreneurship, Vinnytsia National Agrarian University (21008, Vinnytsia, 3, Soniachna Str., e-mail: haetska@ivsau.vin.ua).

ХАЕЦКАЯ Ольга Петровна - кандидат экономических наук, доцент, заведующая кафедрой экономики и предпринимательской деятельности, Винницкий национальный аграрный университет (21008, г. Винница, ул. Солнечная, 3, e-mail: haetska@ vsau.vin.ua).

У ДК 332.2.021.8 : 332.26

DOI: 10.37128/2411-4413-2021-4-10

УКРАЇНСЬКА МОДЕЛЬ РИНКУ ЗЕМЛІ ЕКСКЛЮЗИВ ЧИ «ГІБРИД» ЛАТИФУНДИСТСЬКОї МОДЕЛІ?
ЗАХАРЧЕНКО В.I., доктор економічних наук, професор кафедри адміністративного менеджменту та альтернативних джсерел енерхії, Вінницький національний аграрний університет (м. Вінниця)

У статті розглянуто актуальні питання земельної реформи в Україні в контексті запровадження украӥнської моделі ринку земель сільськогосподарського призначення (далі 3СП).

Метою дослідження є аналіз офіиійної та авторської моделей ринкового обігу ЗСП в Украӥні з позииій сильних $і$ слабких сторін трьох базових моделей - державницької, фермерської та латифундистської.

Показано, щуо державниџька модель, яка практикується в Ізраїлі, Китаї та інших країнах, базується на орендних земельних відносинах -між державою, як власником землі, $i$ колективними агропідприємствами, причому иі відносини регулюються державним земельним органом. Визначено, щзо фермерська модель, як найпоширеніша й найефективніша, має у своїй основі приватну форму власності на землю, яку обробляють переважно малі ци середні фермерські господарства, а орендні земельні відносини доповнюються ринковими. І изі відносини, як наприклад у Польщуі, регулюються державними 